\title{
Narrativa
}

narrativa

Nuova serie

\section{L'Italia come sud nella cultura inglese moderna: un contributo decoloniale}

Luigi Cazzato

\section{(2) OpenEdition}

1 Journals

Edizione digitale

URL: https://journals.openedition.org/narrativa/645

ISSN: 2804-1224

\section{Editore}

Presses universitaires de Paris Nanterre

\section{Edizione cartacea}

Data di pubblicazione: 1 décembre 2017

Paginazione: $29-40$

ISBN: 978-2-84016-289-6

ISSN: $1166-3243$

\section{Notizia bibliografica digitale}

Luigi Cazzato, «L'Italia come sud nella cultura inglese moderna: un contributo decoloniale», Narrativa [Online], 39 | 2017, online dal 01 décembre 2021, consultato il 14 janvier 2022. URL: http:// journals.openedition.org/narrativa/645

\section{c) (†)}

Narrativa est mise à disposition selon les termes de la Licence Creative Commons Attribution 4.0 International. 


\section{L'Italia come sud nella cultura inglese moderna: un contributo decoloniale}

\section{PREMESSE: SUd MOBILE, IMMAGINE FISSA}

$\checkmark$

ualsiasi speculazione sul sud, come su ogni altro punto cardinale, ha bisogno di alcune premesse, in qualche modo concatenate. La prima è quella gramsciana, secondo la quale i rapporti fra i punti cardinali sono reali e tuttavia immaginari, in quanto costruzioni convenzionali che non esisterebbero senza l'uomo e la sua storia:

Ciò si può vedere più chiaramente dal fatto che questi termini si sono cristallizzati non dal punto di vista di un ipotetico e malinconico uomo in generale ma dal punto di vista delle classi colte europee che attraverso la loro egemonia mondiale li hanno fatti accettare dovunque. Il Giappone è Estremo Oriente non solo per l'Europeo ma forse anche per l'Americano della California e per lo stesso Giapponese, il quale attraverso la cultura politica inglese potrà chiamare Prossimo Oriente l'Egitto' ${ }^{1}$.

La seconda premessa è che il sud, nonostante sia una questione immaginativa è pure una questione molto concreta, legata alle condizioni materiali dell'esistenza. In questo senso, è un luogo geografico mobile o come dice Iain Chambers "a mobile placeholder"': un segnaposto così mobile che segna sud anche a nord.

It conjoins multiple localities and temporalities, from the zones of rural poverty in nineteenth-century Europe that conjoins Scandinavia, Scotland, and

1. Gramsci, Antonio, Quaderni del carcere, in Gerratana, Valentino (a cura di), Torino, Einaudi, 1975, pp. 1419-1420.

2. Chambers, Iain, Postcolonial Interruptions, Unauthorised Modernities, London/New York, Rowman \& Littlefield International, 2017, p. 28. 
Ireland with Italy and Greece, to the colonial rampage unleashed by Europe on Africa, Asia and the Americas since $1500^{3}$.

L'ovvia conseguenza è che il sud è più una questione di posizione subalterna che di semplice posizione geografica.

La terza premessa, legata alla condizione di subalternità, è che dal punto di vista epistemologico "we are where we think"4. Per cui, capita spesso che il sud pensi non con la sua testa, quella del luogo geo-sociale di appartenenza, bensì con quella del nord, un luogo epistemico altro egemone.

Una volta evidenziata questa condizione di mutevolezza geo-epistemica, rimane, tuttavia, da rilevare una fissità dalla quale il sud deve decolonizzarsi: quell'imago mundi che a partire dal Rinascimento ha dominato il pianeta e ha visto "il nord seduto sul sud".

\section{QUANDO È STATO INVENTATO IL SUD?}

Si può dire, a grandi linee, che la divisione Nord/Sud (predominante soprattutto dopo la fine della Guerra fredda), abbia preso piede (con guida nordamericana) dopo la Seconda Guerra Mondiale, mentre quella Est/Ovest (con guida europea) abbia dominato il lungo periodo precedente a partire dalla conquista dell'America con l'opposizione, per esempio, "Indie orientali vs Indie occidentali" e poi "Europa vs Oriente". Se l'opposizione Est/Ovest si rifà al paradigma "civiltà/barbarie", quella Nord/Sud al paradigma "progresso/arretratezza" (o "sviluppo/sottosviluppo").

Nella cultura inglese, che io chiamo "meridionista" (di cui parlerò più avanti), la ricorrenza massiccia della parola "sud" e delle sue metafore inizia soprattutto nella seconda metà dell'Ottocento. In precedenza, la sua ricorrenza era più rada e aveva più o meno una valenza geografico-denotativa: a fine Settecento o inizi Ottocento, "Southern" erano le province o il sole d'Italia. Lord Byron, che fu il più "meridionale" degli inglesi italianati (come venivano chiamati gli inglesi accultured sul suolo italiano), in "Stanza to the Po" (1819) parla di sangue meridiano, non meridionale: "his blood / Is all meridian, as if never fanned / By the black wind that chills the polar flood".

\section{Ibid.}

4. Mignolo, Walter, The Darker Side of Western Modernity: Global Futures, Decolonial Options, Duke University Press, Durbam/London, 2011, p. 83.

5. Lord Byron, Selected Poetry of Lord Byron, in Marchand, Leslie A. (a cura di), New York, The Modern Library, 2001, p. 231. 
Tuttavia, nonostante a livello di elocutio la valenza connotativa della parola "sud" appaia tardi rispetto agli altri ambiti nazionali europei (Montesquieu, Goethe, Bonstetten), a causa, probabilmente, dell'egemonia del discorso orientalista ("orientale" o "semi-orientale" sono spesso lessemi preferiti per indicare il sud), la sostanza di quella parola è presente molto prima. Quindi l'"Italia come sud" è un topos ricorrente per tutta la seconda modernità e mano a mano che ci si inoltra in essa, la parola "sud" e i suoi derivati passano dalla dimensione denotativo-geografica a quella connotativo-morale.

Ma cosa intendo per prima e seconda modernità? Intendo una modernità che è lunga abbastanza da contenere la nascita del Nuovo Mondo (coloniale), dominata dagli stati atlantici meridionali (prima modernità), sulla quale si innesta una seconda modernità che vede la nascita del Nuovo Soggetto (razionale e ancora coloniale) a partire dal '700, modernità dominata dagli stati atlantici settentrionali.

$\grave{E}$ in questa seconda fase che avverrebbe una modifica all'interno del binarismo "civiltà/barbarie", poiché i barbari ${ }^{6}$ non venivano più collocati nello spazio ma anche nel tempo: i barbari non erano più "genti mostruose" ma "genti primitive". È un passaggio epistemologico di traduzione della geografia in cronologia, che entrerà in profondità nelle fibre dell'uomo moderno occidentale, il quale colonizzerà non solo lo spazio ma anche il tempo, tramite la "negazione della coevità"’ e l'imposizione della modernità singola.

È un passaggio epistemologico che verrà ufficialmente proclamato nel 1871 dal padre dell'antropologia culturale Edward Burnett Tylor, il quale fissa i tre principali stadi progressivi dell'evoluzione umana: quella dei selvaggi, dei barbari, dei civilizzati. In particolare,

the savage state in some measure represents an early condition of mankind, out of which the higher culture has gradually been developed or evolved $[\ldots]$ the result showing that, on the whole, progress has far prevailed over relapse 8 .

6. Per gli inglesi i barbari più vicini erano gli irlandesi. Edmund Spenser, nel suo A View of the Present State of Ireland (scritto nel 1596 e pubblicato 1633), nelle vesti di poeta/burocrate in Irlanda pensava che la "stubborn nation of the Irish" bisognava portarla "from their delight of licensious barbarisme unto the love of goodnesse and civility" (SPENSER, Edmund, The Works of Edmund Spenser: With Observations on His Life and Writings, London, Henry Washbourne, 1852, p. 482).

7. Con il concetto di "negazione della coevità", Johannes Fabian intende la "tendenza sistematica e persistente a posizionare il referente (o i referenti) dell'antropologia in un Tempo Altro rispetto al presente di chi produce il discorso antropologico" (FABIAN, Johannes, Il tempo degli altri, trad. it. di Lucia Rodeghiero, Napoli, L'Ancora, 2000, p. 62).

8. TAYLOR, Edward Burnett, Primitive Culture: Researches into the Development of Mythology, Philosophy, Religion, Art, and Custom, Cambridge, Cambridge University Press, 2010, p. 28. 
Insomma, l'opposizione discorsiva "progresso/arretratezza", già operante nel '700 (con Edward Gibbon, il marchese de Sade, Johann Hermann von Riedsel) nell'Ottocento di Tylor prepara l'avvento della divisione nord/sud, che si coagulerà in maniera plateale nel Novecento.

\section{RAPporto natura/CUltura nella Modernitì/Colonialità}

Tale è stata l'egemonia inglese nella seconda modernità che la nascita della Englishness e di questa stessa modernità sembrano essere una sola cosa, a discapito, per esempio, dell'italianità: quella dimensione nazionale che, secondo gli inglesi, tarda a nascere proprio perché appartenente alla latitudine sbagliata.

Che si tratti sia di seconda che di prima modernità, la matrice epistemologica è unica: quella che i pensatori decoloniali chiamano "matrice coloniale del potere" nella Modernità/Colonialità. Per Aníbal Quijano la parola modernità è, infatti, coterminus di colonialità, poiché non ci può essere modernità senza colonialità, la quale è il lato invisibile e cionondimeno costitutivo della modernità. E che cosa è la colonialità (del potere)?

Coloniality of power was conceived together with America and Western Europe, and with the social category of 'race' as the key element of the social classification of colonized and colonizers. Unlike in any other previous experience of colonialism, the old ideas of superiority of the dominant, and the inferiority of dominated under European colonialism were mutated in a relationship of biologically and structurally superior and inferior?

Dopo tre secoli di colonialità, registrando che gli etnografi assegnano i popoli barbari al polo della savage life e le nazioni civili a quello della cultured life, Tylor definisce la civiltà in termini di conoscenza positiva delle leggi fisiche del mondo e in termini di potenza degli uomini nel piegare la natura alla loro volontà ${ }^{10}$.

\section{EUROPA SEDUTA SUL MONDO E IL RESTO DEL MONDO SEDUTO SULLA NATURA}

Prima ancora della nascita dell'antropologia culturale, alcuni mappamondi post-rinascimentali contenevano in nuce la definizione di Tylor.

9. Quijano, Aníbal, “Coloniality and modernity/rationality”, in Mignolo, Walter, Escobar Arturo (a cura di), Globalization and the decolonial option, London/New York, Routledge, 2010 , p. 25.

10. Tylor, Edward Burnett, Primitive Culture, cit., p. 24. 


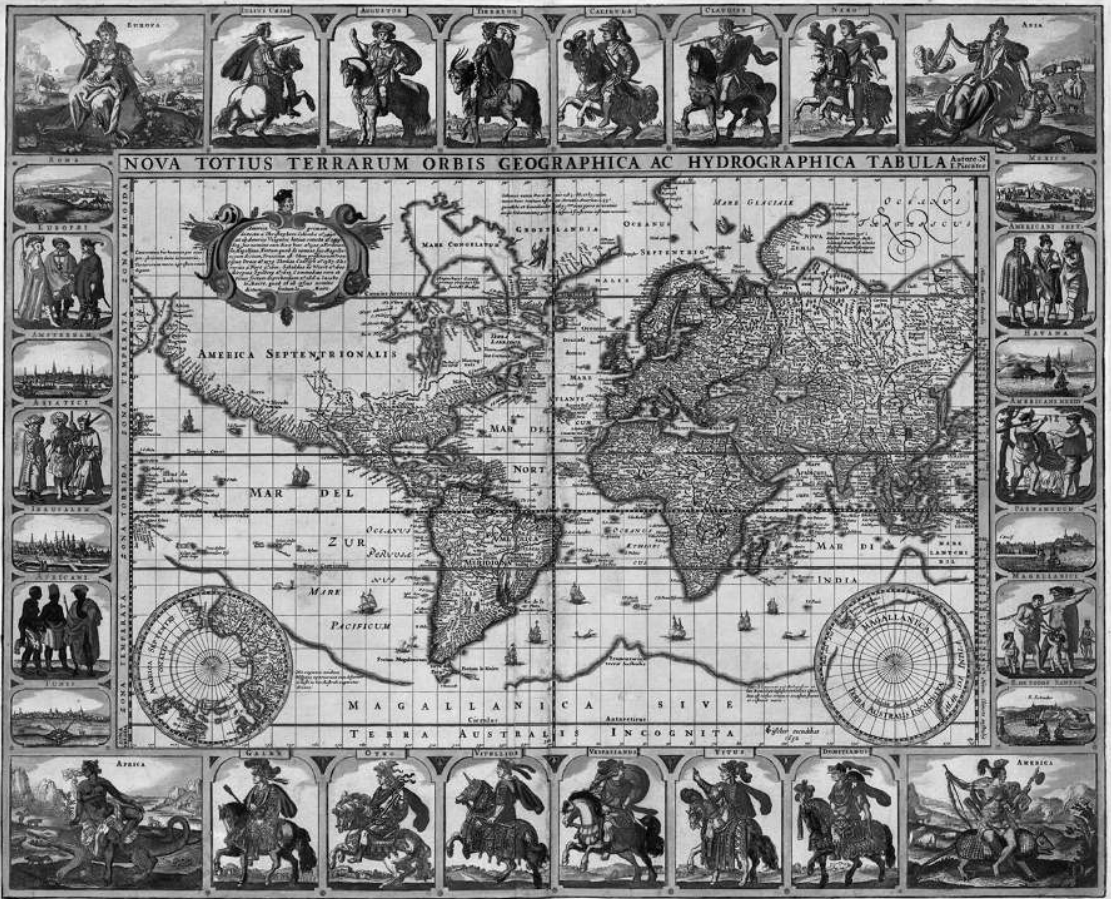

È il caso del mappamondo dell'olandese Nicholas Visscher (1652), che (ri) afferma:

- l'orientamento a nord (rispetto alle mappe medieval-cristiane che venivano orientate, appunto, ad oriente e quelle medieval-islamiche orientate a sud ${ }^{11}$ );

- la proiezione anti-mimetica di Mercatore (frutto del passaggio funzionale in ambito nautico dalla superficie sferica a quella piana con il conseguente ingrandimento delle masse terrestri man mano che si passa dall'equatore ai poli, col risultato grottesco di una Groenlandia estesa quanto l'Africa);

- l'Europa come il solo continente del raggiunto stato di cultura di contro all'alterità degli altri continenti ancora vicini, in varia misura, allo stato di natura, come si evince dalle raffigurazioni dei vari continenti ai quattro angoli della mappa.

11. Eccezione occidentale, poiché ancora orientato a sud, è il mappamondo di Fra Mauro (1459), con palesi influenze arabe. 
Infatti, l'Europa in alto a sinistra è una donna vestita regalmente in un ambiente pastorale; l'Asia in alto a destra vestita elegantemente ma seduta su un cammello; l'Africa semi-nuda seduta su un coccodrillo; l'America semi-nuda anch'essa ma rudimentalmente armata e seduta su un armadillo. Insomma, Europa $=$ Cultura, il resto del mondo $=$ Natura.

Questa equazione viene poi complicata abbastanza da stabilire, attraverso il senso comune che Tylor due secoli dopo registra, "a rough scale of civilisation". E quale era questa scala approssimativa? "Few would dispute that the following races are arranged rightly in order of culture: Australian, Tahitian, Aztec, Chinese, Italian" "12. Insomma, gli italiani rappresenterebbero il top di questo campione razziale. Ma è solo un possibile esemplificativo campione. In realtà, il sottointeso è che all'apice della classifica regnano incontrastati gli inglesi, che non a caso sono in grado di studiare gli altri, redigendo classifiche e provando a se stessi prima che agli altri la loro superiore cultura. Gli inglesi che secondo John Ruskin erano il miglior miscuglio di sangue settentrionale - si assegnarono il pesante fardello, dell'“Imperial duty" che era "Reign or Die"13.

A proposito di sangue settentrionale, ecco come veniva raffigurato l'uomo del nord e del sud due secoli prima di Ruskin in Europa:
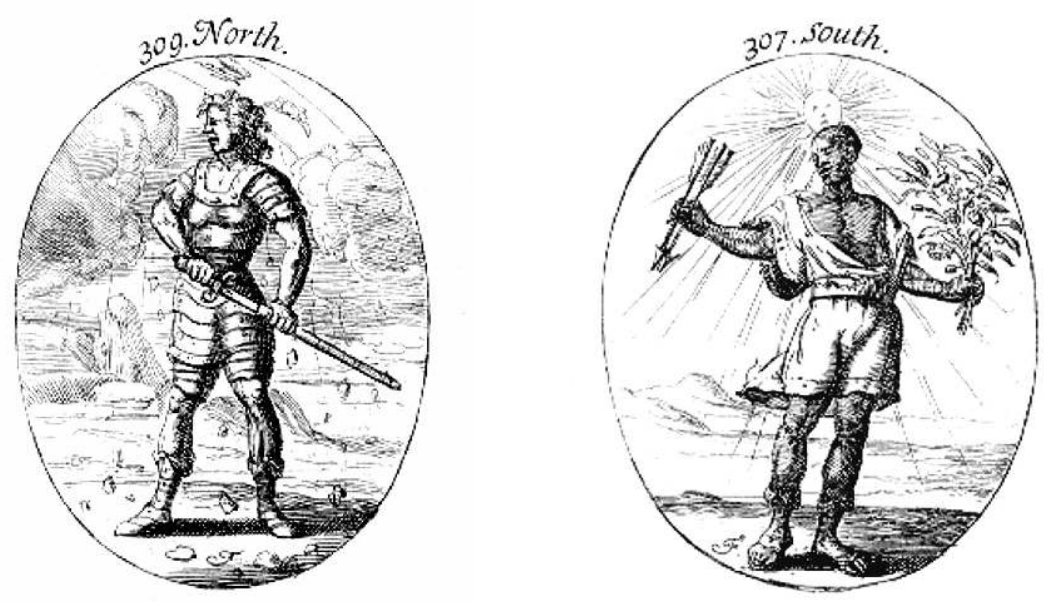

Sono immagini tratte dall'Iconologia (1593-1603) di Cesare Ripa, una vasta raccolta di allegorie largamente diffusa fra '600 e '700 in tutta Europa.

12. Tylor, Edward Burnett, Primitive Culture, cit., p. 24.

13. Ruskin, John, Lectures on Art, Rockville, MD. Arc Manor, 2008, p. 25. 
Il sud, si dice nella didascalia di un'edizione inglese del 1709, è un "Blackmoor Boy", apparentemente mite e arrendevole con "a Sun upon his Head, surrounding him with its Rays". Mentre il nord è un uomo "of a proud aspect; ruddy complexion; [...] His posture, the bravery of the Northern people" e sullo sfondo nuvole minacciose ${ }^{14}$. Insomma, già nell'immaginario colto sei-settecentesco il sud era umile e nero, il nord bianco e intrepido. Tuttavia, qui trattandosi come dice il sottotitolo, della "descrittione dell'imagini universali cavate dall'antichità et da altri luoghi", il sud è scuro e giovane ma dai tratti non ancora irrimediabilmente africani, in qualche modo vicini a quelli dei popoli europei.

\section{MERIDIONISMO: SPAZIO DISCORSIVO DELLA DIFFERENZA IMPERIALE}

Questa sorta di vicinanza mi dà l'occasione per ricordare che nella storia dell'egemonia europea non è esistito solo lo spazio della "differenza coloniale", ma anche quello della "differenza imperiale". Non sono esistiti solo colonizzatori e colonizzati, ma anche "imperi giusti" (il britannico e quello francese) e "imperi sbagliati" (il russo e quello ottomano), insomma un differenziale di potere fra gli imperi. Così Walter Mignolo:

The imperial difference works by using some of the features of the colonial difference and applying them to regions, languages, people, states, etc., that cannot be colonized. A degree of inferiority is attributed to the imperial other that has not been colonized in that it is considered (because of language, religion, history, etc.) somewhat behind (time) in history or, if its present is being considered, marginal (space) ${ }^{15}$.

Se così è, allora ci sono anche imperi o popoli sbagliati poiché non ancora imperi, come quello italiano (almeno nell'Ottocento).

Ora leggiamo questo passo canzonatorio di Edward Said tratto dal suo Orientalismo:

Orientals cannot walk on either a road or a pavement (their disordered minds fail to understand what the clever European grasps immediately, that roads and pavements are made for walking); Orientals are inveterate liars, they

14. RIPA, Cesare, Iconologia, or, Moral Emblems, London, Benjamin Motte, 1709, p. 77.

15. Mignolo, Walter, "Delinking: The Rhetoric of Modernity, the Logic of Coloniality and the Grammar of De-coloniality", in Mignolo, Walter, Escobar, Arturo (a cura di), Globalization and the decolonial option, cit., p. 328. 
are "lethargic and suspicious", and in everything oppose the clarity, directness, and nobility of the Anglo-Saxon race ${ }^{16}$.

Chiunque lo legga non può non pensare che coloro i quali non sanno usare $\mathrm{i}$ marciapiedi non sono solo gli orientali ma anche i meridionali. Quindi non c'è solo l'orientalismo ma anche una formazione discorsiva che Alfred Pfister mi ha aiutato a chiamare "meridionismo"17:

This intra-European "Meridionism" has not had the same far-reaching and devastating political consequences that Orientalism brought upon mankind by legitimizing colonialism, the disempowerment, exploitation, and humiliation of almost all non-European peoples, it has played an incisive role in the formation of British and European cultural self-understanding... ${ }^{18}$

\section{GRIGLIA SEMANTICA MERIDIONISTA}

Ecco allora che l'"Italia come sud" ha la funzione, per contrasto, di forgiare l'identità della nobile e fulgida schiatta anglosassone con l'aiuto di tutto ciò che di negativo aveva rispetto allo standard di civiltà stabilito dalla master narrative imperiale britannica.

Se dovessi sintetizzare le letture fatte negli anni in una serie minima e provvisoria di opposizioni binarie, il repertorio di immagini meridioniste sul sud potrebbe essere così riassunto. Il sud è...

- natura sublime / cultura degradata

- gloria passata / inglorioso presente

- umanità individuale / disumanità politico-religiosa

- soggetto debole-sottomesso-irrazionale / Tradizione imperante

Ovviamente è una griglia che se riferita al nord vede invertite tutte le posizioni, per cui il nord è...

- natura ostile / cultura sublime

- gloria presente / inglorioso passato

16. SAID, Edward W., Orientalism, London, Penguin, 2003, pp. 38-39.

17. "Alle radici del meridionismo" è il sottotitolo del mio Sguardo inglese e Mediterraneo italiano, Milano, Mimesis, 2017.

18. Pfister, Alfred, The Fatal Gift of Beauty: The Italies of British Travellers, AmsterdamAtlanta, Rodopi, 2006, p. 3. 
- umanità politico-religiosa / minor umanità individuale

- soggetto forte-indipendente-razionale / tradizione debole

Riguardo all'ultima opposizione, esemplare è John Ruskin, cultore del gotico veneziano, ma soprattutto dei "Goth" (i popoli gotici), che per lui erano, verbatim, gli inglesi, i francesi, i danesi o i tedeschi, i quali avevano

Strength of will, independence of character, resoluteness of purpose, impatience of undue control, and that general tendency to set the individual reason against authority, and the individual deed against destiny, which, in the Northern tribes, has opposed itself throughout all ages to the languid submission, in the Southern, of thought to tradition, and purpose to fatality ${ }^{19}$.

In poche parole, siamo alle rifiniture del quadro iconografico sei-settecentesco: da una parte l'uomo del nord dallo sguardo rude ma fiero ${ }^{20}$, rivolto verso l'orizzonte e pronto a sguainare la spada, dall'altra l'uomo del sud languidamente sottomesso ai raggi del sole di mezzogiorno, una fatalità che lo opprime e contro cui non oppone alcuna resistenza.

Questa debolezza di carattere e di cultura viene contrapposta alla natura sublime e al passato glorioso del sud, per esempio, da Percy Bysshe Shelley, il quale nel 1818 a Napoli scrive che esistono "two Italies":

one composed of the green earth \& transparent sea and the mighty ruins of ancient times, and aerial mountains, \& the warm \& radiant atmosphere which is interfused through all things. The other consists of the Italians of the present day, their works \& ways. The one is the most sublime \& lovely contemplation that can be conceived by the imagination of man; the other the most degraded disgusting \& odious ${ }^{21}$.

19. Ruskin, John, The Stones of Venice, London, George Allen \& Unwin Ltd., vol. II, p. 200.

20. Interessante, a tal proposito, è la categoria della savageness che Ruskin assegna all'architettura gotica e per omologia alla cultura settentrionale. Rilevato che il termine "gotico" era nato a sud per disprezzare l'arte barbara del nord, non ne condivide, però, il segno negativo: "It is true, greatly and deeply true, that the architecture of the North is rude and wild [...ma] it is in this very character that it deserves our profound reverence" (Ruskin, John, The Stones of Venice, cit., p. 153). Mentre l'antropologia inglese relegava con una mossa epistemologica al passato primordiale la "savageness" dell'altro contemporaneo non-europeo, l'estetica di Ruskin la riabilitava per nobilitare la cultura del nord.

21. Jones, Frederick L. (a cura di), The Letters of Percy Bysshe Shelley, Oxford, Clarendon Press, 1964, p. 67. I corsivi sono miei. 
Shelley, deluso dall'italianità disgregata e succube della tirannia, non fa altro che ingrossare la già pingue e storica figura dell'Italia "paradiso abitato da diavoli", tanto che sarebbe meglio un'Italia senza italiani ${ }^{22}$.

A proposito di cultura degradata, in pieno dibattito sulla "Italian question", il periodico conservatore Blackwood Magazine nel 1859, sostiene l'impossibilità dell'indipendenza nazionale italiana a causa di una decadenza non funzionale ma organica, che ha a che fare con la geografia e la storia, ma soprattutto con la religione:

The religion of the north is suited to northern sternness, and the chill of a northern climate, but cannot pass the southern boundaries of the Alps and the Pyrenees. The lands of the olive and of the vine, of Ceres and of Bacchus, are doomed, we fear, to revel in a religion of festas and of orgies ${ }^{23}$.

Insomma, laddove regna una religione vicina agli standard del paganesimo dei selvaggi (la barbarie presente) o degli antichi (la barbarie passata), non è possibile una forma di auto-governo come quella inglese (l'impero giusto) ma solo una forma dispotica come quella ottomana (l'impero sbagliato).

Ecco allora che l'intero sud d'Europa diventa una questione. Ascoltiamo questo anonimo pubblicista, verosimilmente italiano, che sul periodico liberale Examiner del 1856 lamenta:

Whether constitutional or despotic, it is much the same: the doctors are not satisfied with the condition of the various governments. There are Turkey, and Greece, and Italy and Spain of which the short-coming are held to be lamentable ... It is marvellous, indeed, this contempt with which Northern speak of Southern ... you might imagine yourself in the presence of philosophers of a superior planet condescending to note the lost condition of a fallen race ${ }^{24}$.

E anche quando l'indipendenza, malgrado il pessimismo del Blackwood Magazine, sarà raggiunta, qualcosa non torna. Come non tutto torna alla protofemminista Annie Leigh Smith che, arrivando in Sicilia dall'Algeria, è pronta per

22. Cfr. Luzzi, Joseph, "Italy without Italians: Literary Origins of a Romantic Myth", in MLN, vol. 117, 2002, pp. 48-83.

23. Blackwood's Magazine, vol. LXXXV, gennaio-giugno 1859, p. 369.

24. "North and South - Manin and Mazzini”, Examiner, 9 agosto 1856, p. 497. 
un reportage sulle scuole di una Palermo appena unita al resto dell'Italia. Cosa vi trova?

We found the children fairly up in all the subjects on which we questioned them, with less idea of order and discipline than English boys, with the irritability and quickness which belong to their southern nature, and the incapacity of continued effort, which we in the north are fond of saying is a peculiarity of the feminine $\operatorname{mind}^{25}$.

Paradossalmente, la scrittrice inglese attiva per gli scolari siciliani lo stesso repertorio otherising e disempowering che veniva attivato per il suo stesso genere. Qui la natura meridionale è vicina a quella femminile: disordinata, indisciplinata, irritabile, incapace dello sforzo prolungato, cose di cui implicitamente sono capaci i maschi del nord. È una fortuna quindi che la Sicilia sia stata unita al nord dell'Italia affinché possa approfittare degli "inestimable advantages" del governo di Vittorio Emanuele, un re che viene dal nord e grazie al quale in "20 years the whole character of the people may be modified and improved"26.

Qui è evidente che 1" Italia come sud" comincia a diventare un'espressione impropria. Il processo unitario, attuato da nord, de-meridionalizza parte dell'Italia, annettendola al nord civile, luminoso e industrioso del resto dell'Europa... del nord-ovest, s’intende.

\section{IL SUD COMINCIA, IL PROGRESSO FINISCE}

La risposta precisa, dunque, alla domanda iniziale "quando è stato inventato il sud" è la seguente: il sud è stato inventato quando è stata inventata l'arretratezza, o il progresso (le due necessarie e complementari facce della medaglia della seconda Modernità/Colonialità ${ }^{27}$ ), la cui imperiosa marcia da nord verso sud, a un certo punto, si blocca. Dove? Ce lo dice esattamente non un inglese ma un francese. Per il funzionario napoleonico Auguste Creuzé de Lesser,

25. Sмith, Annie L., "Schools in Palermo", in English Woman's Journal, Ottobre 1863, p. 100.

26. Ibid.

27. Su arretratezza o sottosviluppo come "funzione" dello sviluppo capitalistico, si può vedere il saggio di Ferrari Bravo, Luciano e Serafini, Alessandro, Stato e sottosviluppo. Il caso del Mezzogiorno italiano del 1972, ripubblicato da Ombre Corte, Verona, 2007, p. 29. 
"L'Europe finit à Naples et même elle y finit assez mal. La Calabre, la Sicile, tout le reste est de l'Afrique" 28 .

Siamo ai primi vagiti dell'Ottocento e anche ai primi vagiti della metafora africana che, come sappiamo, nonostante la sua veneranda età gode ancora di ottima salute. Quasi due secoli dopo, sul treno Milano-Reggio Calabria, Nelson Moe ci racconta come una signora fiorentina nel 1983 lo guardò con stupore e commiserazione quando seppe che aveva intenzione di fermarsi a Napoli: non sapeva che "the south was like Africa?"29. Luigi Carlo Farini, collaboratore di Cavour e futuro primo ministro dell'Italia unificata, poco dopo il suo arrivo nel Mezzogiorno scrisse al Conte: "Che barbarie! Altro che Italia! Questa è Affrica" ${ }^{30}$. Infine, disse anche che Garibaldi unì l'Italia, ma divise l'Africa ${ }^{31}$. Tuttavia, come l'impresa unitaria, anche quella divisiva non è riuscita benissimo se è vero che gli italiani non sono arrivati a sprofondare del tutto nel Mediterraneo. Lo temeva Ugo La Malfa negli anni ’70, quando registrava lo sforzo italiano "di arrampicarsi sulle Alpi per guardare all'Europa che avanza" per provare a uscire, quindi, "completamente dal Mediterraneo" 32 .

A distanza di quasi cinquant'anni dallo scritto di La Malfa e dopo venti dall'uscita di Pensiero meridiano, siamo ancora là, penzoloni, appesi a quella catena montuosa, nella speranza di poter entrare nella "vera" Europa e con la paura auto-meridionista di scivolare verso sud, precipitando nel nostro mare.

Luigi Cazzato

Università di Bari

28. Creuzé de Lesser, Auguste, Voyage en Italie et en Sicile fait en 1801 et 1806, Paris, P. Didot, 1806, p. 96.

29. Moe, Nelson J., The View from Vesuvius: Italian Culture and the Southern Question, Berkeley/Los Angeles/London, University of California Press, 2002, p. XIII.

30. Conte Cavour, La liberazione del Mezzogiorno e la formazione del Regno d'Italia, Carteggi di Camillo Cavour, Bologna, Zanichelli, 1949-1954, vol. III, p. 208.

31. Bracalini, Romano, Brandelli d'Italia. 150 anni di conflitti Nord-Sud, Soveria Mannelli, Rubbettino, 2010, p. 31.

32. La Malfa, Ugo, Senza l'Europa avrete il deserto, Soveria Mannelli, Rubettino, 2005, p. 85 . 